\title{
Early Starter - The Early Detection of Delinquency Risk
}

\author{
Maria Marcu1 ${ }^{1}$ Diana Hulea ${ }^{*}$ \\ ${ }^{1}$ General Directorate of Social Assistance and Child Protection Sibiu, 2 Mitropoliei Street, 550179 Sibiu, Romania.
}

KEYWORDS

Deviation

Juvenile delinquency

Prevention

Social problems

\begin{abstract}
A social problem of interest to many scholars today is that of juvenile delinquency. Juvenile delinquency is a serious behavioural problem, manifested through behaviours that deviate from the moral and legal norms of society. It was noted in Europe in the last decade an increase in the number of juvenile delinquents and a decrease in the age of young people who commit acts of delinquency. This requires prevention and intervention measures to be applied as early as possible. Prevention can be achieved only when an early detection of risk is performed. One screening tool for assessing risk is The Strengths and Difficulties Questionnaire. This tool is intended to clarify, in a first rough assessment (a so-called 'screening') of whether a child is about to become an 'early starter'; a child showing signs of an early onset delinquent behaviour. In the city of Sibiu the questionnaire was applied within schools and information was provided by teachers relating to 308 pupils in grades I-IV. The main perception of the target group of this study was that children who have committed crimes, but are not criminally responsible, are primarily troubled kids, not criminals with established patterns of behaviour. Consequently, the social and educational systems and not the justice system should bear the responsibility for this target group. From this perspective, it is important that social, educational and therapeutic activities focus on the various individual problems of each child and family.
\end{abstract}

\section{Juvenile delinquency - risk factors}

In their studies, Loeber, Farrington and Petechuk (2003) reported that children who commit their first delinquent act at around the age of thirteen years old are more likely to become chronic offenders than children who

\footnotetext{
* Contact addresses: marcu_mariaa@yahoo.com (M. Marcu); diana.hulea@yahoo.com (D. Hulea)
} 
commit delinquent acts at a later age. They discovered that minor problems in behaviour leading to delinquency often begin at a very young age.

In recent years, juvenile justice in the USA has adopted a new approach in an attempt to understand the causes of delinquency and work towards its prevention. It is considered that if a child possesses certain risk factors, these factors will increase his/her chances of becoming a delinquent. A risk assessment may aid to determine the type of intervention that will best suit the child's needs and decrease the risk of him/her breaking the law (Farrington 2000).

Next we present a list of risk factors based on the work of Loeber and Farrington (2001). The Childhood Risk Factors for Child Delinquency and Later Juvenile Offending are divided into four categories of factors. First, there are the individual factors which are considered to be the early indicators of antisocial behaviour, emotional factors such as: high behavioural activation and low behavioural inhibition, poor cognitive development, low intelligence and hyperactivity. Second, there are the family factors involving parenting, maltreatment, family violence, divorce, parental psychopathology, family antisocial behaviours, teenage parenthood, family structure, large family size. Third, peer factors associated with violent peers and peer rejection. The fourth category is that of the school and community factors, which are: the failure to bond with school, poor academic performance, low academic aspiration, living in a poor family, neighbourhood disadvantage, disorganized neighbourhoods, concentration of delinquent peer groups and access to weapons.

McCord et al. (2001) consider that risk factors can be divided into three categories: individual (such as prenatal and perinatal factors; psychological, behavioural and mental characteristics), social (such as family structure; peer influences) and community (such as school policies; neighbourhood). A complete review of the risk factors is made by McCord et al. (2001).

Herrenkohl et al. (2000) noticed that a ten year old child that is exposed to six or more risk factors is ten times more likely to commit a violent act by the age of eighteen than a ten year old child exposed to only one risk factor. 
Although researchers use risk factors to detect the likelihood of later delinquency, many children with multiple risk factors never commit delinquent or violent acts. The risk factor may increase the probability of breaking the law, but it does not make it a certainty (Shader 2003).

We consider that an important risk factor is represented by the family environment. Our research points to the fact that the juvenile delinquency is the consequence of: the lack of moral support from the children's parents; the lack of protection and care; the failure of the moral education received by the child.

The deficient family environment (a family that offers no support to the children, with a conflictual environment or parents with behavioural problems) affects the change of the family roles and of the relationships between its members. Ultimately, it affects the functioning of the family and leads to deficiencies in the socialization of children. The occurrence of negative behaviours in the case of the children is the result of the family's inability to provide education, monitoring and parental control, the lack of authority or excessive authority, the insufficient knowing of the children's entourage (group of friends), emotional frustration, inconsistency in the application of rewards and punishments.

Because parents or teachers sometimes ignore nonconformist attitudes or undesirable behaviours are considered minor, as a result of the lack of positive control measures of behaviour, in time, deviant or delinquent stable behavioural schemes are formed. Their appearance and manifestation is a consequence of the failure of socialization and of insufficient social control in family and school.

According to Shader (2003) researchers believe that family is also a protective factor. For example, poverty is often seen as a risk factor, but the presence of supportive, involved parents may mediate the negative influence of poverty to lessen a child's chance of becoming delinquent.

There are situations when nonconformist behaviour, in the absence of adequate social control exercised by individuals invested with authority over the child, may develop into an immoral deviant or delinquent 
behaviour, which violates the moral and legal standards in Romania. 'Immoral conduct' involves a deliberate action, the intentional violation of the social rules, anticipating the immediate and future results of one's actions. They can be the result of deprivation (physical, psychological, educational) or unfavourable educational and social influences (excessive or insufficient authority, lack of supervision and control, negative models). Immoral conduct leads to conflicts with other people and eventually with the low. As these conflicts get stronger and more prolonged, there is a risk of frustration, anxiety and the formation of an immature and unstable personality, emotionally labile and vulnerable. The outcome is the emergence of behavioural disorders with varying degrees of severity (Verza 1993: 116-119). Deviant or delinquent behaviour occurs as a result of negative socialization because of the negative models associated with the individual's desire to be accepted, at any cost in the group with whose subculture she/he identifies herself/himself. The risk of identification with such models becomes even greater for those children that do not have desirable behaviour role-models during their development.

Starting from the idea of negative socialization and negative learning, Cohen considers delinquency as an attribute of certain subcultures that bring together individuals who are unable to access social values (Cohen 1986).

Deviance, and delinquency as an aggravating form of deviance, is characterized by the inability of the individual to adapt to social and legal norms. From the social point of view deviance is an action that goes beyond the institutional boundaries of acceptable tolerance. From a legal perspective, the deviant behaviour is considered to be delinquent behaviour when it violates the law. Behavioural manifestations fall under the category of crime when the behaviour represents a social threat.

The concept of deviance appeared when American sociologist Sellin (1938 apud Dragomirescu 1976: 31) attempted to define the genesis of social crime. He formulated the first definitions of the deviant behaviour. After Sellin deviance is a set of behaviours that are in contradiction with the 
written and the unwritten rules of society or are against the institutional order. In a broader sense deviance signifies the deviation from a given set of social rules (Rădulescu 1998: 17).

Deviant behaviour is defined as the kind of behaviour that deflects and violates the rules, the principles, the behavioural models and the values that are characteristic to the society (Batâr 2003).

Deviance is the violation of social norms and rules. The term 'deviance' covers a much wider area than crime or delinquency (called 'criminal deviance') because it includes the violations of criminal law, all the deviations from socially acceptable and desirable behaviour (Rădulescu 1994).

Among the forms of social deviance there is also the delinquency (or crime) that affects the most important values and social relations protected by legal rules. This represents all deeds that violate the criminal laws, and require the use of negative sanctions, organized by specialized agents of social control (police, justice, and so on). Although delinquency is a juridical phenomenon, governed by the rules of criminal law, it is primarily a social phenomenon, with negative and destructive consequences for the security of individuals and groups.

Juvenile delinquency 'includes all acts and deeds with criminal character committed by young people before reaching the age of criminal majority' (Banciu 2000: 211) and occurs as a result of lack of responsibility in family and school (Rădulescu 1990).

Article 113 of the Romanian Criminal Code states that a minor who has not reached the age of 14 years old is not criminally liable. Any minor who is aged between 14 and 16 years old is not criminally liable unless it is proven that the offender is with discernment and with clear intention to harm. According to the law a minor who has turned 16 is criminally liable. The risk factors for the occurrence of behavioural disorders may be:

a) Unbalances in the family (separated families, alcohol abuse, aggressiveness, neglect, poverty, lack of education, overprotective 
parents or parents that are indifferent towards their children, negative parental models);

b) Teachers that guide themselves strictly by the curriculum, without targeting the continuity in the process of socialization of children, or discrimination based on social status of the children;

c) The neighbourhood subculture can adversely affect a child's education, especially when she/he is neglected by family and school. In this situation the child will seek those who will accept him/her and she/he will find shelter among these groups where s/he is accepted (Dublea et al. 2005).

Therefore, the main perception of the target group of this study is that children who have committed crimes, but are not criminally responsible, are primarily troubled children and young people, not criminals with established behaviour. Consequently, the social and educational systems and not the justice system should bear the responsibility for this target group. From this perspective it is important that social, educational and therapeutic activities focus on the various individual problems of each child and family (Bendit 2010: 6).

Romanian law has a special chapter on the protection of the child who has committed a criminal act and is not criminally liable. According to the Romanian law, in cases of the children who commit criminal deeds it is necessary to adopt a special measure of protection (specialized supervision or placement). The authorities that are responsible for the establishment of these measures are the Commission for Child Protection, in cases where there is the parental consent or at the direction of the Court if parental consent doesn't exist.

The protection measure of specialized supervision means keeping the children in the family provided they meet certain requirements, such as:

- attending school;

- making use of day care services;

- undertaking medical treatment, counselling or psychotherapy (if necessary); 
- avoid going to certain places or having contact with certain persons (Bendit 2010: 30).

If the child cannot remain with the family or it or if the child fails to fulfil the obligations stated by the specialized supervision measure, the Commission for Child Protection or, where appropriate, the Court, may order the child's placement within the extended family or foster family as well as compliance with the obligations mentioned above (Law 272/2004).

The placement in a specialized residential service can be decided if the deed which violates the criminal laws committed by a child presents a high level of social danger or if the child continues to commit criminal acts.

Government Decision no. 1439/2004 on specialized services for children who have committed a criminal offense and not criminally liable approves the establishment, organization and functioning of these services. According to this law, the service may be:

- day services,

- family services and

- $\quad$ residential type services.

Government Decision no. 1439/2004 sets out the objectives of the services, the categories of staff and their obligations.

The need to develop specialized services is rooted in the UN Convention on the Rights of the Child, which sets out the core values that should underpin the approach of a State regarding juvenile justice. According to the Article 40 (1), children in conflict with the law are entitled to treatment according to the sense of personal dignity and values, which should reinforce the child's respect for the human rights and the fundamental freedoms of others. It should also take into consideration the child's age and the need to facilitate his integration into the society and the need to assume a constructive role in society.

Children have the right to be treated in a manner appropriate to their age and their degree of maturity. They are entitled to a procedure which respects their right to privacy, the right to be heard and to understand procedures that they are entitled to in respect of their interests throughout 
the process. Where possible, international standards require protecting children from the negative effects of procedures and stipulates that any treatment applied should be proportionate to the circumstances and the offence committed. Also be taken into consideration is he need to promote the well-being and continuous education of children, and the need for them to play a constructive role in the society (Bendit 2010: 30-31).

\section{Statistics on juvenile delinquency}

Regarding juvenile delinquency, significant changes have taken place; an increasing number of children are now involved in crimes and other violent deeds. The National Authority for Child Protection (ANPDC 2013) provides us with the following statistics on juvenile delinquency. From the total number of crimes committed in 2000 in Romania, 7.2\% of them had children as authors, similar to the percentage recorded in 1999 (7.1\%). From the total number of violent crimes committed by children, $90.6 \%$ were directed against people aged 14 to 17 years. However, the majority of criminal deeds committed by children were committed against property, representing 70\% of the total.

National educational reform has been rapidly evolving, but not always followed but the positive effects that were expected did not always happened. The extension of compulsory education to 10 classes is an important measure because it raises the educational level of the general population. At the same time, the main problems of the educational system are caused by the instability of the legislative measures taken, by the fact that teachers are not financially motivated and by the large differences between urban and rural areas in terms of material conditions and of the level tuition (Bendit 2010: 21).

With a value of $79.7 \%$ in the $2007-2008$ school year, school rate of tuition (the graduation rate of pupils) at all educational levels increased by approximately $6 \%$ compared to the 2002-2003 school year. The fact that the number of students in higher education has tripled in the last 15 years has 
also contributed to the situation presented by the numbers above.

Compared to the value of $0.6 \%$ in the 2000-2001 school year, the school dropout rate reached 2\% in the 2007-2008 school year, as it is shown by the statistics provided by the Ministry of Education and Research in 2008. The Population census conducted in 2002 showed that more than 75,000 people aged between 15 and 24 years were illiterate (ANPDC 2013).

Prostitution and international trafficking of the children became alarming phenomena. The reports of the Ministry of Administration in 20052008 show a gradual decrease in the number of cases of human trafficking, both in terms of total number of victims up to 55\% (from 2251 people in 2005 to 1240 people in 2008), as well as the number of victims among children, who are annually $15-16 \%$ of the total number of victims.

In 2008 there were 186 child victims, representing a decrease of $36 \%$ compared with 2007, of which:

- 93 children were trafficked abroad,

- 93 children were trafficked in Romania (which means an increase in internal traffic from $44 \%$ in 2007 to $50 \%$ in 2008).

The distribution by gender of child victims was: 163 girls (88\%) and 23 boys $(12 \%)$. In comparison to the previous years, the 14-17 years age group remains the main group from which the children were trafficked - 175 children (94\%) (Bendit 2010: 28).

Sexual exploitation remains the main purpose of child trafficking, both in the country and abroad:

- 138 children (74\%) - for sexual exploitation,

- 48 children $(26 \%)$ - to work in agriculture, begging, criminal deeds.

The main countries of destination for external trafficking remained Italy and Spain and, to a lesser extent, Greece, UK, Germany, France, Netherlands, Belgium, Czech Republic (Bendit 2010: 28).

The situation of children involved in drug offences has gotten worst. In the last few years, Romania has become a transit country for drugs, one where drugs are sold and consumed. The number of drug users younger than 18 years has increased in parallel with the decrease of the consumers' 
age (up to 13-14 years old). Studies conducted by Save the Children Organization showed that nearly $10 \%$ of high school students said they had used drugs at least once (Bendit 2010: 29).

The statistics provided by The National Authority for Child Protection in 2007 and 2008 shows which were the most common criminal deeds committed by children who were investigated by The General Directorate of Social Assistance and Child Protection and what measures have been applied.

Table 1. The most common criminal deeds committed by children and the measures implemented

\begin{tabular}{cccccccc}
\hline Year & Total cases & Theft & Robbery & Injury & Prostitution & Rape & Murder \\
\hline 2007 & 4449 & 3591 & 119 & 58 & 15 & 49 & 4 \\
\hline 2008 & 3899 & 2932 & 153 & 95 & 3 & 32 & 4 \\
\hline Year & Other & $\begin{array}{l}\text { Children who } \\
\text { relapsed (\%) }\end{array}$ & $\begin{array}{l}\text { Decisions of the } \\
\text { commission for } \\
\text { child protection }\end{array}$ & $\begin{array}{l}\text { Foster care } \\
\text { or placement }\end{array}$ & $\begin{array}{l}\text { Specialized } \\
\text { supervision }\end{array}$ \\
\hline 2007 & 613 & 9 & & 1049 & 95 & 954 \\
\hline 2008 & 680 & 16.18 & & 1186 & 125 & 1061 \\
\hline
\end{tabular}

Source: Bendit 2010: 32.

\section{Screening - the early detection of delinquency risk}

Researchers believe that inadequate parental guidance and supervision is the starting point for aggressive or antisocial behaviour (Patterson et al. 1991). The deficiency of the educational climate in the family may generate the phenomenon of school maladjustment. In relation to the child teachers can notice some elements in the children's behaviour allowing for the early identification of the risk of pre-delinquent behaviour. Teachers can identify rehabilitation methods and techniques in order to rectify the educational mistakes made by the family, or any other environment that influenced the child.

It is noted, in the last decade, a decrease of the age of children who 
commit criminal acts and therefore the Romanian and European legislation aims at preventing and combating juvenile delinquency and also aims at defending the rights and safety of children who have committed crimes and promoting their physical, mental and social welfare. Research conducted in Europe on juvenile delinquency, in many developed countries led to similar results, allowing for some general conclusions: in many cases, the 'career' of young people with deviant behaviour begins at an early age. Therefore, this issue must be approached with measures of intervention applied as early as possible.

If the child commits anti-social deeds at a young age, the risk of escalation and consolidation of this behaviour is higher. Patterson et al. (1991) refer to this situation as the development of anti-social behaviour with an early start (early-starters).

There has been identified another group of children who do not show anti-social behaviour through adolescence. These are children with a later onset of anti-social behaviour ('late onset'). The two models were analyzed in long-term studies in several countries and have already been confirmed and accepted. Children with early onset need special support from the persons responsible for them (parents and extended family) and from the state institutions. If these children do not receive appropriate external support in order to learn positive alternative behaviour, problems persist.

It was found that most of the children who commit criminal deeds are boys. Girls represent a small percentage, so preventive measures should be targeted mainly at boys. We noticed that the delinquent children are usually strongly influenced by family (parents) and school (teachers). The nature of this influence depends on the cultural differences between nations and the research showed that it is more important in southern Europe than in the north. The importance of the family decreases as the child grows older and the influence of friends increases. As a result, for the children, the family has a very important role in preventing behaviours that degenerate into criminal behaviour (Bendit 2010: 44). 
Table 2. Social characteristics of groups of children with early onset and late onset of the aggressive behaviour

\begin{tabular}{lcc}
\hline & $\begin{array}{c}\text { Early onset } \\
\text { (starts early, persistent) }\end{array}$ & $\begin{array}{c}\text { Late onset } \\
\text { (limited to adolescence) }\end{array}$ \\
\hline Beginning & $\begin{array}{c}\text { 2-4 years old/ } \\
\text { preschool }\end{array}$ & $\begin{array}{c}\text { Late childhood/ } \\
\text { adolescence }\end{array}$ \\
\hline $\begin{array}{l}\text { Accompanied by hyperactivity/ } \\
\text { impulsivity }\end{array}$ & frequently & infrequent \\
\hline $\begin{array}{l}\text { Accompanied by behavioural } \\
\text { disturbances/problems at } \\
\text { School }\end{array}$ & frequently & infrequent \\
\hline Social skills & deficient & existing \\
\hline Problematic family situation & frequently & infrequent \\
\hline Attenuation rate & almost $50 \%$ & almost $90 \%$ \\
\hline Ratio boys: girls & $4: 1$ & $2: 1$ \\
\hline
\end{tabular}

Source: Bendit 2010: 86 .

A screening tool of the risks of becoming an 'early starter' is The Strengths and Difficulties Questionnaire. The questionnaire is part of the tools used in a program implemented in Hamburg, Germany, for children in risk situations which targets groups of children between 4-17 years old. The information from the questionnaire can be provided for parents or teachers that are in daily contact with the children

This tool is intended to clarify, in a first rough assessment (a so-called 'screening') if it is a case where the child is about to become an 'early starter' (children with early onset delinquent behaviour) or not. If the conclusion is affirmative then the child must be investigated in detail using the form that identifies the risk of building or escalating aggressive or anti-social behaviour.

\section{The early detection of delinquency risk at pupils from the city of Sibiu}

The research that we present in this study is a result of an experience exchange with colleagues from Hamburg, who presented at Sibiu the Strengths and Difficulties Questionnaire as tool used in a program implemented in Germany. This instrument was developed by Kindler in 
2008 for indicating the risk factors for the anti-social behaviour of pupils under the age of fourteen.

In the city of Sibiu the Strengths and Difficulties Questionnaire was applied in 2011 within schools and it gathered information about 308 pupils in grades I-IV. The information from the questionnaire was provided by the teachers who are in daily contact with the children. The sampling used is unrepresentative, because it includes a number of 308 pupils in grades I-IV. The classrooms included in our study were those that teachers agreed should participate in the research.

The aim of the study was to identify from the population of pupils from the city of Sibiu the population of pupils that shows that kind of behaviours that could include them in the 'early starter' category.

Table 3. The gender structure of the sample

\begin{tabular}{lll}
\hline Gender & Value & Percentage \\
\hline Boys & 139 & $44 \%$ \\
\hline Girls & 169 & $56 \%$ \\
\hline Total & 308 & $100 \%$ \\
\hline
\end{tabular}

From the 308 pupils that were included in our study, 38 pupils were identified with risk of an early onset of anti-social behaviour ( 23 boys and 15 girls) and 29 pupils at the limit of anti-social behaviour (17 boys and 12 girls). Of the 38 pupils that were identified with the risk of an early onset of anti-social behaviour we encountered deviant behaviour such as theft and violence, or in some cases both of them. Of the pupils at limit of anti-social behaviour it was noticed that their behaviours had a negative effect on the general atmosphere of the class.

We can observe from our study that most of the children who present the risk of an early onset of anti-social behaviour and most of the children at the limit of anti-social behaviour are boys. We can conclude than our research shows the same results as other research conducted in the Europe, from this point of view, as the general conclusions in Europe was that most of the children who commit criminal deeds are boys, according to the study 
Gender in the Juvenile Justice System (Institutul National de Criminologie 2006).

Table 4. Pupils with risk of an early onset of anti-social behaviour and the pupils at the limit of anti-social behaviour from the total of children investigated

\begin{tabular}{lcccc}
\hline & Risk & Limit & No risk & Total \\
\hline Value & 38 & 29 & 241 & 308 \\
\hline Percentage & $12 \%$ & $10 \%$ & $78 \%$ & $100 \%$ \\
\hline
\end{tabular}

Table 5. Comparative presentation (boys-girls) regarding the pupils with risk of an early onset of anti-social behaviour and the pupils at the limit of anti-social behaviour

\begin{tabular}{ccc}
\hline & Risk & Limit \\
\hline Boys & 23 & 17 \\
\hline Girls & 15 & 12 \\
\hline
\end{tabular}

Of the 38 pupils with risk of an early onset of anti-social behaviour, using the Strengths and Difficulties Questionnaire, we tried to identify the difficulties in the areas of concentration, behaviour and relationships. The results were: 14 cases of minor difficulties, 21 cases of obvious difficulties and 3 cases of major difficulties.

Table 6. Regarding the extent of the difficulties in the areas of concentration, behavior and relationships.

\begin{tabular}{lccccc}
\hline & $\begin{array}{l}\text { No } \\
\text { difficulties }\end{array}$ & $\begin{array}{l}\text { Minor } \\
\text { difficulties }\end{array}$ & $\begin{array}{l}\text { Obvious } \\
\text { difficulties }\end{array}$ & $\begin{array}{l}\text { Major } \\
\text { difficulties }\end{array}$ & Total \\
\hline Value & 0 & 14 & 21 & 3 & 38 \\
\hline Percentage & $0 \%$ & $37 \%$ & $55 \%$ & $8 \%$ & $100 \%$ \\
\hline
\end{tabular}

We can notice that $63 \%$ of the pupils with risk of an early onset of antisocial behaviour have obvious and major difficulties in the areas of concentration, behaviour and relationships, as resulted from the answers provided by the teachers who completed the questioners. Regarding period 
of time these problems started to occur, for 33 pupils this took place over a period of 1 year and for 5 pupils over a period between 6 to 12 months.

Table 7. The period of time since the problems of concentration, behaviour and relationships started to occur

\begin{tabular}{lccc}
\hline & Over 1 year & 6 to 12 months & Total \\
\hline Value & 33 & 5 & 38 \\
\hline Percentage & $87 \%$ & $13 \%$ & $100 \%$ \\
\hline
\end{tabular}

Table 8. Details regarding the characteristics of the difficulties in the areas of concentration, behaviour and relationships

\begin{tabular}{|c|c|c|}
\hline & $\begin{array}{l}\text { No. of pupils with risk } \\
\text { of an early onset of } \\
\text { anti-social behaviour }\end{array}$ & $\begin{array}{l}\text { No. of pupils at the } \\
\text { limit of anti-social } \\
\text { behaviour }\end{array}$ \\
\hline \multicolumn{3}{|l|}{ Concentration } \\
\hline No difficulties & 0 & 12 \\
\hline Minor difficulties & 14 & 11 \\
\hline Obvious difficulties & 21 & 6 \\
\hline Major difficulties & 3 & 0 \\
\hline \multicolumn{3}{|l|}{ Behaviour } \\
\hline Does not disturb & 5 & 15 \\
\hline Disturbs in a small degree & 12 & 6 \\
\hline Disturbs in a high degree & 19 & 7 \\
\hline Disturbs in a very high degree & 2 & 1 \\
\hline \multicolumn{3}{|l|}{ Relationship } \\
\hline Does not affect the relationship & 0 & 16 \\
\hline Affects the relationship in a small degree & 13 & 9 \\
\hline Affects the relationship in a high degree & 22 & 3 \\
\hline $\begin{array}{l}\text { Affects the relationship in a very high } \\
\text { degree }\end{array}$ & 3 & 1 \\
\hline \multicolumn{3}{|l|}{ Disposition } \\
\hline Does not affect the child's disposition & 0 & 14 \\
\hline Affects the disposition in a small degree & 9 & 8 \\
\hline Affects the disposition in a high degree & 24 & 5 \\
\hline $\begin{array}{l}\text { Affects the disposition in a very high } \\
\text { degree }\end{array}$ & 5 & 2 \\
\hline \multicolumn{3}{|l|}{ Burden } \\
\hline Is not a burden & 2 & 14 \\
\hline Is a burden in a small degree & 12 & 9 \\
\hline Is a burden in a high degree & 22 & 5 \\
\hline Is a burden in a very high degree & 3 & 1 \\
\hline
\end{tabular}


From this study we noticed that $87 \%$ of the children with risk of an early onset of anti-social behaviour the concentration, behaviour and relationships problems were present for over 1 year. When we studied the details regarding the characteristics of the difficulties that children at risk of an early onset of anti-social behaviour and children at the limit of anti-social behaviour have in the areas of concentration, behaviour and relationships, we obtained the following results.

Of the extent to which these difficulties influenced the child's affectivity in the sense of a sad mood from the total of 38 pupils that present the risk of an early onset of anti-social behaviour, 6 children were not affected in any way, 13 children were less affected were, 14 children were affected in a high degree and 3 children were affected in a very high degree.

Table 9. Regarding the extent to which these difficulties influenced the child's affectivity in the sense of a sad mood

\begin{tabular}{|c|c|c|c|c|}
\hline & $\begin{array}{l}\text { Affected in a small } \\
\text { degree }\end{array}$ & $\begin{array}{l}\text { Affected in a high } \\
\text { degree }\end{array}$ & $\begin{array}{l}\text { Affected in a very } \\
\text { high degree }\end{array}$ & Total \\
\hline Value & 9 & 24 & 5 & 38 \\
\hline Percentage & $24 \%$ & $63 \%$ & $13 \%$ & $100 \%$ \\
\hline
\end{tabular}

We can notice that $76 \%$ of the pupils investigated are affected by the concentration, behaviour and relationships problems that they have at school, in the sense that they have a sad mood.

Table 10. Regarding the areas in which the pupils have difficulties - No of cases

\begin{tabular}{cccc}
\hline Emotional problems & Behavioural problems & Hyperactivity & Problems with peers \\
\hline 17 & 19 & 35 & 22 \\
\hline
\end{tabular}

Regarding the relationships with their peers, they were negatively affected as follows: less affected in 13 cases, affected in high degree in 22 cases and affected in a very high degree in 3 cases. 
Table 11. Regarding the level in which the relationship with their peers was negatively affected

\begin{tabular}{lc}
\hline Not affected & $0 \%$ \\
\hline Affected in a small degree & $34 \%$ \\
\hline Affected in a high degree & $58 \%$ \\
\hline Affected in a very high degree & $8 \%$ \\
\hline
\end{tabular}

Analyzing the figure above, we can notice that at $66 \%$ of the pupils had negative relationships with their peers. We analyzed the extent to which the pupil's difficulties are affecting pupils themselves in the learning process. The results showed the learning process was less affected for 9 children, affected to a high degree for 24 children and affected in a very high degree 5 of the children. Next we analyzed the extent to which the pupil's difficulties are affecting the entire class learning process. The results showed the entire class' learning process was affected as follows: not affected in 2 cases, less affected in 12 cases, affected in high degree in 22 cases and highly affected in 2 cases.

Table 12. Comparative presentation of the extent to which the pupil's difficulties are affecting the pupil itself and the extent to which the pupil's difficulties are affecting the entire class' learning process

\begin{tabular}{lcc}
\hline & Difficulties for the child & Difficulties for the class \\
\hline Not affected & $0 \%$ & $5 \%$ \\
\hline Less affected & $23 \%$ & $31 \%$ \\
\hline Affected in a high degree & $63 \%$ & $58 \%$ \\
\hline Affected in a very high degree & $14 \%$ & $6 \%$ \\
\hline
\end{tabular}

We can notice that the pupil's difficulties are affecting to a high degree both the pupils themselves and the learning process and the entire class in the learning process. Regarding deviant behaviour of the pupils that presented risk of an early onset of anti-social behaviour, 12 pupils stole from home or school, 14 pupils have shown violent behaviour towards other children, and both types of behaviour were present in 10 pupils. 
Table 13. Regarding the manifestation of deviant behaviour

\begin{tabular}{lcccc}
\hline & Theft & Violence & Both & Total \\
\hline Value & 10 & 12 & 14 & 36 \\
\hline Percentage & $28 \%$ & $33 \%$ & $39 \%$ & $100 \%$ \\
\hline
\end{tabular}

We can notice that from the 38 pupils that presented risk of an early onset of anti-social behaviour, 36 (94.7\%) of them manifested delinquent behaviour (theft, violence or both). From the 308 pupils that were included in our study, 38 pupils were identified with risk of an early onset of antisocial behaviour and 29 pupils at the limit of anti-social behaviour emphasizing that many children are subject to protective influences. The protective influence may come from their families or even from the teachers. This means that only a small number of the children that are in a risk of becoming delinquents develop in such a manner. Children with risk of an early onset of anti-social behaviour need special support from their families, the school and other institutions in order to learn positive alternatives to their behaviour.

\section{Conclusions}

Generally, children commit crimes that are not very serious. As the age decreases, the criminal deeds that children commit are less serious. As it was shown in the theoretical part of this paper, as they grow older, the seriousness of their deeds increases, so it is very important to pay special attention to these behaviours, to not permit them escalate into something more serious.

The main conclusion that we can draw is that from a population of 308 pupils, 38 pupils were identified with risk of an early onset of anti-social behaviour and 29 pupils at the limit of anti-social behaviour, representing $32 \%$ of the total of the population. $63 \%$ of the pupils with risk of an early onset of anti-social behaviour have difficulties in the areas of concentration, behaviour and relationships problems that are present for over 1 year. Also for $66 \%$ of the pupils the relationship with their peers is negatively affected 
in a high degree and in a very high degree by the concentration, behaviour and relationships problems that they have.

Another important conclusion is that from the 38 pupils identified with the risk of an early onset of anti-social behaviour, 36 of them manifested delinquent behaviour (theft, violence or both). The delinquency brought to surface the acute need for education both in the family and in school. Parents and teachers can notice bad nonconformist attitudes or undesirable behaviours. If this behaviour is considered to be minor, as a result of the lack control measures, in time, the behaviour may develop into a deviance or delinquency. We consider that juvenile delinquency is a consequence of the failure of socialization and of insufficient social control in family and school.

Researchers recommend integrating the following types of school and community prevention programs: behaviour management programs, social competence promotion, conflict resolution and violence prevention, bullying prevention, afterschool recreation programs, mentoring programs, school organization programs and comprehensive community interventions

The main conclusions of our study match the results of other similar studies. Because most of the necessary conditions for later serious and violent juvenile offending begin in childhood, the Study Group on Very Young Offenders (presented in Child Delinquents: Development, Intervention and Service Needs 2001) strongly urges that efforts to reduce serious forms of delinquency should shift from a focus on adolescent delinquents and more serious chronic juvenile offenders to a focus on child delinquents.

\section{References:}

Autoritatea Națională pentru Protecția Drepturilor Copilului (ANPDC). 2013. "Statistici." www.copii.ro.

Banciu, Dan and Sorin Rădulescu. 1994. Corupția şi crima organizată în România. Bucureşti: Editura Continent XXI. 
Banciu, Dan. 2000. Elemente de sociologie juridică. Bucureşti: Editura Lumina Lex.

Batâr, Dumitru. 2003. Sociologie: probleme teoretice şi analize ale investigațiilor de teren. Sibiu: Psihomedia.

Bendit, René, ed. 2010. "Linii directoare, metodologii i instrumente pentru o abordare orientată spre lumea reală a serviciilor pentru copii în situații de risc, din perspectivă socială şi pedagogică." Bucureşti: Autoritatea Națională pentru Protecția Drepturilor Copilului. http:/ / www.copii.ro/Files/Manual\%20copilul\%20care\%20a\%20sav arsit $\% 20$ fapte $\%$ 20penale $\% 20$ si $\% 20$ nu.pdf.

Cohen, Albert K. 1966. Deviance and Control. New-Jersey: Prentice-Hall.

Dragomirescu, Virgil. 1976. Psihosociologia comportamentului deviant. Bucureşti: Editura Ştiințifică şi Enciclopedică.

Dublea, Aurel, Sofia Luca, Radu Moisescu, Călin Scripcaru, Cătălina Luca, and Mirela Vlad. 2005. Ghid de practici institutionale in instrumentarea cauzelor cu minori. Iaşi: Asocia ia Alternative Sociale.

Farrington, David P. 2000. "Explaining and Preventing Crime: The Globalization of Knowledge - The American Society of Criminology 1999 Presidential Address." Criminology 38 (1): 1-24.

Guvernul României. 2004. “Hotărâre nr. 1439 din 2 septembrie 2004 privind serviciile specializate destinate copilului care a săvârşit o faptă penală şi nu răspunde penal." Monitorul Oficial Part I (872).

Herrenkohl, Todd I., Eugene Maguin, Karl G. Hill, J. David Hawkins, Robert D. Abbott, and Richard F. Catalano. 2000. "Developmental Risk Factors for Youth Violence." The Journal of Adolescent Health: Official Publication of the Society for Adolescent Medicine 26 (3): 176-86.

Institutul National de Criminologie (INC). 2006. "Gender in the Juvenile Justice System." http://www.criminologie.ro/INC/Lang/Romana Study/PROJECTGIJJS_FINALREPORT_ENG.pdf.

Institutul Na ional de Statistică (INSSE). 2002. "Recensământul populației şi locuintelor 2002". www.insse.ro.

Loeber, Rolf and David P Farrington. 2001. Child Delinquents: Development, Intervention, and Service Needs. Thousand Oaks: Sage Publications.

Loeber, Rolf, David P. Farrington, and David Petechuk. 2003. "Child Delinquency: Early Intervention and Prevention." Child Delinquency. Bulletin Series. https://www.ncjrs.gov/pdffiles1/ojjdp/186162.pdf.

McCord, Joan, Cathy S. Widom, Nancy A. Crowell, and National Research Council (U.S.). 2001. Juvenile Crime, Juvenile Justice. Washington, DC: National Academy Press. 
Ministerul Educației. 2008. "Raport asupra stării sistemului național de învățământ, 2008". http:/ / www.edu.ro/index.php/articles/10913.

Ministerul Muncii, Familiei şi Protecției Sociale. 2008. "Raportul național strategic privind protectia socială şi incluziunea socială (2008-2010)". http://www.mmuncii.ro/pub/imagemanager/images/file/Domeni i/Incluziune \% 20si \% 20asistenta \% 20sociala/Raportari\% 20si \% 20indica tori/170609Raportul\%202008\% 20-\%202010\%20Final\%20octombrie 202008_doc.pdf.

Ministerul Muncii, Familiei şi Protecției Sociale. 2009. "Buletinul statistic trimestrial în domeniul muncii şi protecției sociale" 1 (65). http://www.mmuncii.ro/j3/index.php/ro/transparenta/statistici/ buletin-statistic?id=871:buletin-statistic-trimestrial-in-domeniulmuncii-si-protectiei-sociale-nr-1-65-2009\&catid=29:domenii

Parlamentul României. 2004. "Legea 272 din 21 iulie 2004 privind Protecția i Promovarea Drepturilor Copilului." Monitorul Oficial Part 1 (557).

Parlamentul României. 2009. “Legea nr. 286 din 17 iulie 2009 privind Codul Penal." Monitorul Oficial Partea I (510).

Patterson, Gerald, Deborah Capaldi, and Lew Bank. 1991. “An Early Starter Model for Predicting Delinquency." In The Development and Treatment of Childhood Aggression, edited by Debra J. Pepler and Kenneth $\mathrm{H}$. Rubin. Hillsdale: L. Erlbaum Associates.

Rădulescu, Sorin M. 1998. Sociologia devianței. Bucureşti: Editura Victor.

Shader, Michael. 2004. Risk Factors for Delinquency: An Overview. Washington D.C.: US Department of Justice \& Office of Juvenile Justice and Delinquency Prevention.

Verza, Emil. 1993. Psihologia vârstelor. Bucure ti: Editura Hyperion XXI.

Wasserman, Gail A. and Angela Seracini. 2001. "Family Risk Factors and Interventions." In Child Delinquents: Development, Intervention, and Service Needs, edited by Rolf Loeber and David P Farrington, 165-89. Thousand Oaks: Sage Publications. 